Article

\title{
Social Identity and Risk Perception Explain Participation in the Swiss Youth Climate Strikes
}

\author{
Adrian Brügger $1, * \mathbb{C}$, Moritz Gubler ${ }^{2,3,4}$, Katharine Steentjes ${ }^{5,6}$ and Stuart B. Capstick ${ }^{5,6}$ \\ 1 Department of Consumer Behaviour, Faculty of Business, Economics and Social Sciences, University of Bern, \\ 3012 Bern, Switzerland \\ 2 Institute for Research, Development and Evaluation, Bern University of Teacher Education, \\ 3012 Bern, Switzerland; moritz.gubler@phbern.ch \\ 3 Oeschger Centre for Climate Change Research, University of Bern, 3012 Bern, Switzerland \\ 4 Institute of Geography, University of Bern, 3012 Bern, Switzerland \\ 5 Centre for Climate Change and Social Transformations, Cardiff University, Cardiff CF10 3AT, UK; \\ steentjesk@cardiff.ac.uk (K.S.); capsticksb@cardiff.ac.uk (S.B.C.) \\ 6 Tyndall Centre for Climate Change Research, Cardiff University, Cardiff CF10 3AT, UK \\ * Correspondence: adrian.bruegger@imu.unibe.ch; Tel.: +41-31-631-8675
}

Received: 17 October 2020; Accepted: 15 December 2020; Published: 18 December 2020

check for updates

\begin{abstract}
Since late 2018, young people around the world have united to demand greater action on climate change. Aside from their stated concerns and demands, however, very little is known about why young people have been joining this growing movement. Using a large sample $(N=4057)$ of people in Switzerland aged between 14 and 25, we show that social identity is most strongly associated with participation, followed by beliefs about the effectiveness of youth strikes, level of education, and worry about climate change. Our findings affirm the relevance of both climate change risk perceptions and social identity-related processes for collective climate change action, and pave the way for promising opportunities in theory development and integration. The study also provides lessons for those who seek to maintain and increase collective action on climate change: concern about climate change is an important motivating factor, but social identity processes are at least as relevant for young people's participation.
\end{abstract}

Keywords: climate change; Fridays for Future; youth climate strikes; collective action; social movements; social identity; risk perception

\section{Introduction}

From small beginnings, youth strikes on climate change have grown rapidly, achieving much in a short time: extensive media attention, support from almost 27,000 scientists [1], and the foundation of numerous like-minded regional, national, and international groups such as "parents for future" and "artists for future." The youth strikes are likely to have increased public awareness and concern about climate change [2,3] and to have added momentum for changes in the political landscape, especially in Europe [4]. To develop a theoretically driven understanding of the motivations for people's participation in the youth strikes, we draw on insights from two established lines of research: public risk perceptions and research on collective action.

Previous research has investigated what motivates people to take personal action on climate change [5,6] and why they participate in collective action in general [7-9]. However, little is known about the motivations of climate change strikers; in particular, why young people have joined this most recent wave of strikes (for a notable exception, see Han and Ahn's narrative analysis [10]). While concern about climate change can be considered an intuitive and reasonable explanation for such 
participation, previous research also draws attention to a range of other relevant factors influencing people's involvement in protest, including a person's moral convictions, how they see themselves in relation to a social movement, and their emotional investment in it [10-12].

Survey-based research offers some insights into wider public support for collective action and drivers of public sphere activism in the context of climate change. Previous research has considered attitudes and beliefs (e.g., distrust in national governments' capacity to reduce climate change), emotions (e.g., worry and anger), and motives (including the desire to express personal views and to push for action on climate change) $[13,14]$. Empirical insights from large-scale public opinions and actions are almost exclusively focused on adult samples (for exceptions, see $[15,16]$ ), and provide only limited insights into what drives motivation of young people to take part (or not take part) in climate change strikes.

The participation and motivations of young people in activism may be distinct from that of older individuals, not least because of differences between age groups in terms of how they perceive the operation of political processes and their part in this [17]. There are at least three aspects that limit the usefulness of previous research to better understand the reasons behind the youth strikes on climate change. First, survey research has not directly compared those who do and do not strike, although this provides a crucial opportunity to test hypotheses about reasons for participation [8]. Second, while some survey research on climate activism is based on academic research and established theories $[13,14,18]$, the limited amount of research carried out on the youth climate strikes has not yet been able to investigate established theories, over and above consideration of more ad hoc assumptions and intuitions (e.g., $[15,16])$. The lack of research on the theoretical foundations of this new wave of protest constrains the ability to understand why young people do or do not participate in climate strikes. Third, survey research to date on this topic has been exclusively descriptive. This is valuable in order to summarize the prevalence of different views in terms of frequencies and percentages. However, to better understand the contribution of different factors and processes, there is a need for more detailed analyses via inferential statistical approaches.

\subsection{Research on Collective Action}

To better understand young people's motivation to strike for climate change, we draw on research around collective action, which we conceptualize as action that people take "together to achieve a common goal" [19] (p. 1) and which may include diverse actions such as signing a petition, street protests, or striking. While collective action is conceptualized as a group-based activity, in practice it is often measured using individual-level data (e.g., self-report of participation in collective action). Converging evidence from political science, sociology, economy, history, and psychology have identified several socio-psychological determinants of participation in collective action [20-22]. The seminal social identity model of collective action (SIMCA) developed by van Zomeren and colleagues [22] suggests that participation in collective action can be explained by three psychological constructs: (1) social identity, in terms of "people's subjective sense of identification with a group" (p. 505); (2) perceived injustice, which is understood as a "subjective experience of unjust disadvantage [of one's social group]" (p. 505) and includes both a non-affective (knowledge about inequality) and an affective component (group-based anger); (3) efficacy beliefs, these being subjective expectations about the effectiveness of collective action (response efficacy: how helpful is this in achieving a shared goal?) and of one's group (collective efficacy: can we achieve our goal through joint efforts?).

Recent theoretical work suggests that the violation of moral convictions (i.e., firm beliefs about what is right and wrong [23]) should be considered as an additional, more distal predictor of collective action $[9,24]$ that "could bring individuals together who share these convictions" [24] (p. 382). From a theoretical perspective, this predictor seems therefore more flexible than the subjective perception of injustice, which tends to focus on the relative position of one's own social group (cf. [22]). Moreover, anger may not be the only emotion that can motivate collective action. Positive emotions such 
as group-based pride might also motivate collective action [20,22] (but see [25] for a more critical evaluation).

Although this extended version of the SIMCA is a promising approach to investigate youth climate strikes, some of its features may constrain its applicability to this type of collective action. In particular, research on collective action has typically assumed a strong degree of identification and membership within a group or social movement. Such group membership may be evident in some contexts, but it is unclear whether there are established in-group identities in the context of youth climate strikes. In the case of youth strikes, strikers could identify with each other because they have similar opinions about the consequences and mitigation of climate change. Some researchers argue that relevant group membership could be more flexible in this way, and be based on shared opinions [20] or even identification with a wider community of humanity $[25,26]$.

\subsection{Risk Perceptions and Climate Change}

A complementary area of research that provides insights into people's thinking about and action on climate change is risk perception. This work originates from an appreciation that non-experts evaluate risks associated with hazards or technologies differently than expert assessors. This has historically led to a need to understand how people perceive risks and how they evaluate options for risk management (e.g., [27,28]).

Research on public risk perceptions of climate change has identified a range of factors that explain large-scale support for climate change policies and individual behavioural intentions. Established factors shaping risk perception and support for risk mitigation strategies include the following: (a) perceived negative consequences of climate change; (b) negative affect associated with this global threat (e.g., worry); (c) personal values including political orientation; (d) knowledge and understanding of climate change; and (e) the belief that oneself or someone else is able to do something to address climate change (efficacy beliefs) [5,6,29-36]. Recent evidence also highlights the role of moral concerns as a belief that shapes support for mitigation policies across countries [37]. More broadly, demographic variables such as gender, education, and age have been established as strong predictors of climate change concern and support for related actions (e.g., $[33,38])$.

Van der Linden proposed the Climate Change Risk Perception Model (CCRPM) to bring together the key psychological predictors of climate change risk perception [30]. This model suggests that only the interplay between cognitive, cultural, and emotional factors can explain how judgements about climate risks are formed and how they vary between people or groups.

While much risk research has focused on national or representative populations, other approaches have considered how differences in risk perceptions emerge between different groups or on the basis of different personal experience. Influential work in this vein has examined differences in risk perception in the context of vulnerability to specific risks, such as people living in high-risk areas (e.g., flood-affected areas [39,40]) or vulnerable groups (e.g., farmers [41]).

As suggested by the CCRPM and others (e.g., [42]), risk perception always needs to be understood as a consequence of the social context it developed in. The social amplification of risk framework, for example, stresses the ways in which social networks can magnify risk issues [42]. The so-called cultural theory of risk perception likewise suggests that people selectively emphasize or play down risks such as climate change depending upon their affiliation with more broad-based ways of viewing the world [43]. While these frameworks do not offer precise predictions for how young people are likely to perceive and respond to climate change, they do highlight that group affiliation and interpersonal processes are likely to be important influences in this respect.

\subsection{Young People and Climate Change}

A key characteristic of the climate strike movement is that it has been founded and sustained by young people $[13,14]$. Although previous research has addressed the precursors and barriers of climate change engagement (e.g., [5,6,44-46]), most studies have been limited to samples of the general 
public, and thereby largely ignored children, adolescents, and young adults $[47,48]$. This raises the question about whether and how young people differ from adults with respect to climate action and the underlying psychological mechanisms, including, for example, those described in the SIMCA [22] and in research on risk perceptions (e.g., $[5,6,29])$. There is good reason, at least, to expect that young people have the potential to be influenced through the types of social identity processes postulated in the SIMCA [49].

Some recent opinion polls provide evidence that climate change is seen as a more important issue by younger people than by older age groups. A poll conducted in the UK in 2019 showed that $63 \%$ of 11-to-18-year olds picked "the environment and climate change" as one of the top three issues facing the UK [50]. In the adult ( $\geq 18$ years) poll from the same year, only $27 \%$ reported the environment among their top issues. Corner et al. [47] suggest that across European countries, young people tend to have similar or higher levels of concern than adults. Risk perceptions may be higher among younger people for at least two reasons. First, young people are more likely to have learnt about climate change through formal education and to be aware of its negative effects $[47,51]$. Second, contemporary young people may see climate change as more relevant because they are more at risk to personally experience serious impacts of climate change in the future; indeed, Fisher [52] argues that young people become active on climate change because they recognize their obligations as current and future citizens to address the issue. However, the empirical evidence on this point is limited. For one thing, risk perceptions seem to be very similar between parents and their children, suggesting that perceptions do not necessarily vary by age [53]. For another, the correlation between age and climate risk perceptions tends to be weak and inconsistent (although there is a trend for younger people to more strongly believe that climate change is a real threat and to have more negative feelings about it $[30,54])$.

Young people could also differ from older people in terms of identity-related processes. During adolescence, world-views and both personal and social identities are still forming $[55,56]$. This plasticity seems to reduce ideology-based motivated reasoning and increase susceptibility to new information [56,57], which in turn could facilitate contact and identification with people from other social groups and increase the likelihood of joining them in strikes. Corner et al. [47] further suggest that being open to new ideas and thinking deeply about issues may promote engagement with climate change by young people (see also [58]), though other pressures, such as a concern with self-image and social recognition, may run counter to the types of value bases that more broadly drive engagement with climate change [47].

A final characteristic that sets young people apart is that political events during adolescence and early adulthood often have formative and long-lasting effects on later political attitudes and behaviours [57,59-61]. In connection with the finding that participating in collective action strengthens group adhesion, solidarity, and social identity [62], it could be expected that the climate strikes contribute to a new generation of citizens, voters, parents, decision-makers, business people, and politicians with shared concern for climate change (and maybe a partially shared social identity, too). To the extent that participation also increases the typically low climate-related efficacy beliefs among adolescents [47], the emerging generation would not only be concerned but also empowered.

\subsection{The Present Research}

To summarize, research on risk perceptions and social identity-based activism has the potential to elucidate why young people participate in strikes. However, the applicability and explanatory power of these theoretical perspectives remain uncertain in the context of the youth strikes movement. The present research aims to close this gap in the literature by testing how well the constructs of an extended version of the social identity model of collective action [22], which we henceforth refer to as ESIMCA and those from the risk perception framework (e.g., [30]) can explain participation in the youth climate strikes. This enables us to consider factors that derive from disparate but potentially relevant fields across the social science of climate action. 


\section{Materials and Methods}

\subsection{Data Collection, Respondents, and Study Design}

Between May and September 2019, a total of 4057 respondents completed a cross-sectional online survey questionnaire. To test the power of different determinants to explain strike participation, a sample was needed that included both strikers and non-strikers [8]. Respondents were recruited mainly through emails sent to principals and secretary offices of approximately 450 lower secondary, upper secondary, and professional schools in the German-speaking part of Switzerland. Depending on their decision, our request was then either denied, forwarded to the teaching staff, or sent directly to the students. Thus, a portion of respondents filled out the questionnaire in regular school lessons, whereas others completed it in their leisure time. Because such general samples often include only a small proportion of people who participate in collective action similar to the youth strikes [8], we additionally encouraged members of climate strike networks to share our invitation to participate with others in their groups on WhatsApp (a mobile phone messenger application). This we deem an appropriate recruitment strategy for a respondent sample that meets particular characteristics, as opposed to being representative of the wider population. Of those who indicated their gender, $2377(61 \%)$ were female and $1519(39 \%)$ were male. The mean age was $17.0(S D=2.46$; range: $14-25)$. Compared to the population of 14 to 25 years old people living in the German-speaking parts of the country, female respondents were overrepresented $(61.0 \%$ vs. $48.4 \%)$, and our sample was in general younger than the wider population (17.0 vs. 19.8 years; [63]). With respect to education, we could only partially compare our sample to the wider population of the same age range in the German-speaking parts of Switzerland because we could not ascertain how many people in this specific group were attending an educational institution at the tertiary level. The proportion of students in primary school and upper secondary school was higher in our sample than in the reference population $(+0.3 \%$ and $+5.6 \%)$, whereas fewer respondents were attending lower secondary school than in the reference population $(-5.8 \%$; these figures were obtained upon request from the Federal Statistical Office; the closest publicly available data can be found here: [64]).

About $35 \%$ of the respondents had taken part in climate strikes, of which $71.4 \%$ were female compared to $55.4 \%$ in the non-striker sample. With regard to the age structure, the two subsamples were well balanced (mean: 16.9 and 17.2 years, respectively; see Table 1 for detailed profiles of strikers and non-strikers).

Table 1. Descriptive statistics for non-strikers, strikers, and total sample.

\begin{tabular}{cccc}
\hline & Non-Strikers & Strikers & All \\
\hline $\begin{array}{c}\text { Respondents } \\
\mathrm{N}\end{array}$ & 2640 & 1417 & 4057 \\
\hline Age & & & \\
Mean $(S D)$ & $16.9(2.4)$ & $17.2(2.5)$ & $17.0(2.5)$ \\
Range & $14-25$ & $14-25$ & $14-25$ \\
\hline Gender & & & \\
Male & $1131(44.6 \%)$ & $388(28.6 \%)$ & $1519(39.0 \%)$ \\
Female & $1407(55.4 \%)$ & $970(71.4 \%)$ & $2377(61.0 \%)$ \\
Education & & & $14(0.3 \%)$ \\
Primary & $13(0.5 \%)$ & $1(0.1 \%)$ & $936(23.1 \%)$ \\
Lower secondary & $752(28.6 \%)$ & $184(13.0 \%)$ & $2671(66.0 \%)$ \\
Upper secondary & $1672(63.6 \%)$ & $999(70.6 \%)$ & $424(10.5 \%)$ \\
Tertiary & $193(7.3 \%)$ & $231(16.3 \%)$ & $3.7(1.1)$ \\
Worry & & & $1-5$ \\
Mean $(S D)$ & $3.4(1.1)$ & $4.3(0.8)$ & \\
Range & $1-5$ & $1-5$ & \\
\hline
\end{tabular}


Table 1. Cont.

\begin{tabular}{|c|c|c|c|}
\hline & Non-Strikers & Strikers & All \\
\hline \multicolumn{4}{|l|}{ Severity } \\
\hline Mean $(S D)$ & $64.8(19.9)$ & $75.1(13.6)$ & $68.4(18.6)$ \\
\hline Range & $0-100$ & $0-100$ & $0-100$ \\
\hline \multicolumn{4}{|l|}{ Urgency } \\
\hline Mean $(S D)$ & $4.1(1.5)$ & $5.0(1.1)$ & $4.4(1.4)$ \\
\hline Range & $1-6$ & $1-6$ & $1-6$ \\
\hline \multicolumn{4}{|c|}{ Moral conviction } \\
\hline Mean $(S D)$ & $4.6(1.1)$ & $5.5(0.6)$ & $4.9(1.1)$ \\
\hline Range & $1-6$ & $1-6$ & $1-6$ \\
\hline \multicolumn{4}{|l|}{ Anger } \\
\hline Mean $(S D)$ & $4.0(1.3)$ & $5.1(0.9)$ & $4.4(1.3)$ \\
\hline Range & $1-6$ & $1-6$ & $1-6$ \\
\hline \multicolumn{4}{|l|}{ Pride } \\
\hline Mean $(S D)$ & $3.7(1.2)$ & $4.7(0.9)$ & $4.0(1.2)$ \\
\hline Range & $1-6$ & $1-6$ & $1-6$ \\
\hline \multicolumn{4}{|c|}{ Efficacy beliefs } \\
\hline Mean $(S D)$ & $4.1(1.1)$ & $5.1(0.6)$ & $4.4(1.1)$ \\
\hline Range & $1-6$ & $1-6$ & $1-6$ \\
\hline \multicolumn{4}{|c|}{ Social identity } \\
\hline Mean $(S D)$ & $3.0(1.2)$ & $4.6(1.0)$ & $3.5(1.4)$ \\
\hline Range & $1-6$ & $1-6$ & $1-6$ \\
\hline
\end{tabular}

\subsection{Survey Design and Measures}

The survey questionnaire was designed to learn more about why young people participate in climate strikes. Respondents first indicated whether they had previously participated in any climate strikes. Then they answered questions related to risk perceptions, the social identity model of collective action [9], and sociodemographic characteristics. Participants also answered questions on pro-environmental behaviours and motivations that are not included in the current study's analysis. Respondents took on average $15 \mathrm{~min}$ to answer the questions.

Risk perceptions. Three indicators measured risk perceptions: (1) Worry assesses the level of affective risk perception. We asked respondents how worried they were about climate change on a five-point Likert scale ( $1=$ not at all worried, $5=$ extremely worried [65]). For this question, respondents could also choose "Don't know," which we coded as a missing value. (2) Severity measures more cognitive aspects of risk perception. Respondents used a sliding scale (range: 0-100) to indicate how large they thought the negative effects of climate change would be "if we do not reduce greenhouse gas emissions soon." They indicated severity of impact for the following: where you live, in other parts of the world, for people your age, for future generations, and for plants and animals (Cronbach's $\alpha=0.83$; for survey measures using similar operationalizations, see $[29,66,67])$. (3) Urgency was measured using the single item "Climate change is the most important problem we face at the moment" $(1=$ strongly disagree, 6 = strongly agree).

Moral convictions. We used three items to assess moral convictions about the need to act on climate change (see [68]). To make answering the questions easy, the items were phrased in concrete terms and were directly related to climate change (e.g., "We have a responsibility to protect the climate for future generations"; for a similar operationalization, see [69]). The items were rated on a six-point Likert scale ( $1=$ strongly disagree, $6=$ strongly agree; Cronbach's $\alpha=0.85)$.

Anger. Respondents were asked to indicate their agreement with three statements about anger (e.g., "It annoys me greatly that politicians do so little for climate protection"; 1 = strongly disagree, $6=$ strongly agree; Cronbach's $\alpha=0.82$; for similar operationalizations, see [70-72]). 
Perceived injustice. Respondents indicated their level of agreement with three statements about injustice (e.g., "I find it unfair that those who are not responsible for climate change suffer"; $1=$ strongly disagree, $6=$ strongly agree [69]). To avoid problems with multicollinearity (see next section), we excluded this construct from the analyses.

Pride. Pride was assessed with three statements (e.g., "I am satisfied when I think of what the climate strikes have already achieved"; 1 = strongly disagree, $6=$ strongly agree; Cronbach's $\alpha=0.88$; for a similar operationalization, see [72]).

Efficacy beliefs. The survey questionnaire assessed two types of efficacy beliefs that we treated as a single dimension (see next section): the first focused on the extent to which respondents believed that climate strikes were an effective strategy to address climate change (response efficacy). It included four statements (e.g., "Climate strikes can motivate private individuals to do more for climate protection"; $1=$ strongly disagree, 6 = strongly agree; for a similar operationalization, see [73]). Respondents then indicated how much they agreed with three statements referring to young people's ability to help advancing action on climate change (collective efficacy; e.g., "Together we as young people can see to it that more is done in Switzerland to protect the climate"; $1=$ strongly disagree, $6=$ strongly agree; Cronbach's $\alpha=0.91$; for similar operationalizations, see [69,74]).

Social identity. Four statements were used to assess respondents' 'subjective sense of identification' [22] (p. 505) with climate strikers (e.g., "I have a lot in common with young people who take part in climate strikes"; $1=$ strongly disagree, $6=$ strongly agree; Cronbach's $\alpha=0.89$; for similar operationalizations, see [72,75]).

\subsection{Detecting and Addressing Multicollinearity}

To identify possible problems stemming from highly correlated predictors, we inspected the correlations between predictors (Table S1 in Supplementary Materials) and computed the variance inflation factor (VIF) for each. None of the predictors exceeded the commonly used VIF cut-off $(>5)$, but the correlation coefficient between the two types of efficacy exceeded the cut-off of $r=0.80$ [76]. Because several other ESIMCA predictors were also highly correlated ( $r \mathrm{~s} \geq 0.70)$, we performed a series of maximum likelihood-based exploratory factor analyses with an oblique rotation (oblimin) to examine whether some of the ESIMCA predictors model should be combined.

In the first factor analysis, we set the number of factors to the number of constructs in the ESIMCA model. Of the seven resulting factors, five were theoretically meaningful (Table S2 in Supplementary Materials): Factor 1 included all but one of the efficacy items. Factor 2 included the four social identity items. Factor 3 was a mixture of anger and injustice items. Factor 4 included the three pride items. Factor 5 included the three moral conviction items. (Factor 6 included only one item with a substantial loading; Factor 7 had no items with substantial loadings.)

Next, we removed the two poorly structured factors (Factors 6 and 7). The resulting solution still had two factors that included items from different constructs. We decided to keep the first of these that included the efficacy beliefs (Factor 1, Table S3 in Supplementary Materials). However, for conceptual clarity, we removed the injustice items that were associated with the anger items (Factor 3, Table S3 in Supplementary Materials).

After these alterations and removal of one efficacy item, a conceptually clear structure with five factors was obtained; it was used for the main analyses of this article (Table S4 in Supplementary Materials; Kaiser-Meyer-Olkin (KMO) measure of sampling adequacy $=0.97$; Bartlett's test of sphericity, $\chi^{2}(190)=59,904.09, p<0.001$; root mean square of the residuals $[R M S R]=0.01$; Tucker-Lewis Index of factoring reliability $(\mathrm{TLI})=0.98$, root mean square error of approximation $[\mathrm{RMSEA}]=0.04$ ). Note that for the sake of transparency, the Supplementary Materials also include a version of the main analysis (regression) that used the theoretically anticipated constructs instead of those derived from the factor analyses (Table S6 in Supplementary Materials). 


\subsection{Statistical Analyses}

We constructed a series of separate logistic regression equations with four different blocks to predict participation in strikes. To be able to compare the relative importance of the explanatory variables, we standardized them prior to the analysis. The standardized coefficients (odds ratios) can be interpreted in a similar manner to those in ordinary least-square linear regressions, such that "one standard deviation increase in $\mathrm{X}$ is associated with a $b^{*} A$ unit change in logit $(\mathrm{Y})^{\prime \prime}$ [77] (p. 1416). (A table with unstandardized odds ratios can be found in Table S5 in Supplementary Materials). The first regression model included sociodemographic variables (age, gender, education.) The second model consisted of the risk perception indicators worry, perceived severity, and urgency. The third model included the ESIMCA predictors moral conviction, anger, pride, efficacy beliefs, and social identity. Assessment of the second (risk perception) and third models separately allowed us to gauge their unique contribution to explaining strike participation. The fourth model incorporated all predictors described above in order to account for shared variance between them. For constructs assessed with several items, we used the arithmetic mean of all retained items. For those interested in finer-grained analyses, Table S7 in Supplementary Materials also includes the bivariate correlations between all individual construct items and participation in strikes. Overall, the correlations between individual items and participation were very similar to those that involved the aggregated constructs. All statistical tests were two-tailed. To conduct the analyses and prepare this article, we used the statistical software $\mathrm{R}$ and $\mathrm{R}$ studio [78,79] and several $\mathrm{R}$ packages [80-87].

\subsection{Data Availability}

The data supporting the conclusions of this manuscript are available in the Open Science Framework, https://osf.io/z5h3y.

\subsection{Ethical Approval and Consent}

Ethical approval was granted by the departmental Research Ethics Committee of Author Adrian Brügger.

\section{Results}

A first look at Table 1 reveals that strikers tend to be more worried about climate change $(M=4.3$, $S D=0.8$ vs. $M=3.4, S D=1.1)$ and perceive it as more severe $(M=75.1, S D=13.6$ vs. $M=64.8$, $S D=19.9)$ and urgent $(M=5.0, S D=1.1$ vs. $M=4.1, S D=1.5)$ than non-strikers. They also have stronger moral convictions $(M=5.5, S D 0.6=$ vs. $M=4.6, S D=1.1)$, report higher levels of anger $(M=5.1, S D 0.9=$ vs. $M=4.0, S D=1.3)$, pride $(M=4.7, S D=0.9$ vs. $M=3.7, S D=1.2)$, efficacy beliefs $(M=5.1, S D=0.6$ vs. $M=4.1, S D=1.1)$, and social identity than the non-strikers $(M=4.6, S D=1.0$ vs. $M=3.0, S D=1.2)$.

When used as explanatory variables, the sociodemographic variables uniquely explained $11 \%$ of the variance in strike participation. It was found that younger $(\beta=-0.35, S E=0.05, p<0.001)$, female $(\beta=0.31, S E=0.04, p<0.001)$, and higher educated participants $(\beta=0.73, S E=0.05, p<0.001)$ were more likely to participate (Table 2 ). These patterns mirror previous research on perception of and action on climate change (e.g., [6]; for reviews, see [30,88]).

In the risk perception model, which explained more than twice as much variance as the sociodemographic variables (Pseudo $R^{2}=0.26$ ), a person's level of worry about climate change best explained participation ( $\beta=1.00, S E=0.06, p<0.001$ ). The other two risk variables-perceived severity and urgency of climate change-were also both positively associated with participation in strikes $(\beta=0.14, S E=0.05, p<0.01$ and $\beta=0.20, S E=0.05, p<0.001)$.

The ESIMCA model accounted for almost half of the variance in strike participation (Pseudo $\left.R^{2}=0.47\right)$. In this model, social identity was the construct that shared most variance with participation $(\beta=1.50, S E=0.08, p<0.001)$. The second most powerful explanatory variable in the ESIMCA model 
was efficacy beliefs, which included (a) beliefs about how effective climate strikes are to raise awareness and increase efforts to mitigate climate change (response efficacy) and (b) beliefs about the extent to which young people are able to achieve these goals through joint efforts (group efficacy; these efficacy items were combined into a single construct because of their strong correlation; see Supplementary Materials). The stronger these beliefs were, the more the respondents tended to participate in strikes $(\beta=0.42, S E=0.08, p<0.001)$. When compared against each other, the ESIMCA variables explained participation better than the risk perception variables (larger pseudo $R^{2}$ and smaller log likelihood and AIC, Table 2).

Table 2. Logistic regression models predicting participation $(0=$ no; $1=$ yes $)$ in climate strikes.

\begin{tabular}{|c|c|c|c|c|c|}
\hline & $r$ & Sociodemographic & Risk Perception & ESIMCA & Full Model \\
\hline Age & $\begin{array}{c}0.07^{* * *} \\
{[0.04,0.10]}\end{array}$ & $\begin{array}{c}-0.355^{* * *} \\
{[-0.45,-0.25]}\end{array}$ & & & $\begin{array}{c}-0.33^{* * *} \\
{[-0.46,-0.20]}\end{array}$ \\
\hline $\begin{array}{l}\text { Gender (ref: } \\
\text { male) }\end{array}$ & $\begin{array}{c}0.16^{* * *} \\
{[0.13,0.19]}\end{array}$ & $\begin{array}{c}0.31^{* * *} \\
{[0.24,0.38]}\end{array}$ & & & $\begin{array}{c}0.02 \\
{[-0.08,0.11]} \\
\end{array}$ \\
\hline Education & $\begin{array}{c}0.21^{* * *} \\
{[0.18,0.24]}\end{array}$ & $\begin{array}{c}0.73^{* * *} \\
{[0.62,0.83]}\end{array}$ & & & $\begin{array}{c}0.59^{* * *} \\
{[0.45,0.72]}\end{array}$ \\
\hline Worry & $\begin{array}{c}0.42^{* * *} \\
{[0.39,0.45]}\end{array}$ & & $\begin{array}{c}1.00^{* * *} \\
{[0.90,1.10]}\end{array}$ & & $\begin{array}{c}0.37^{* * *} \\
{[0.23,0.51]}\end{array}$ \\
\hline Severity & $\begin{array}{c}0.27^{* * *} \\
{[0.24,0.29]}\end{array}$ & & $\begin{array}{c}0.14^{* *} \\
{[0.04,0.24]}\end{array}$ & & $\begin{array}{c}-0.22 * * * \\
{[-0.35,-0.09]}\end{array}$ \\
\hline Urgency & $\begin{array}{c}0.28^{* * *} \\
{[0.25,0.31]}\end{array}$ & & $\begin{array}{c}0.20^{* * *} \\
{[0.10,0.30]}\end{array}$ & & $\begin{array}{c}-0.18^{* * *} \\
{[-0.31,-0.05]}\end{array}$ \\
\hline Moral conviction & $\begin{array}{c}0.38^{* * *} \\
{[0.35,0.40]}\end{array}$ & & & $\begin{array}{c}-0.0002 \\
{[-0.16,0.16]}\end{array}$ & $\begin{array}{c}-0.06 \\
{[-0.25,0.13]}\end{array}$ \\
\hline Anger & $\begin{array}{c}0.40^{* * *} \\
{[0.37,0.42]}\end{array}$ & & & $\begin{array}{c}0.12 \\
{[-0.02,0.26]}\end{array}$ & $\begin{array}{c}0.08 \\
{[-0.08,0.24]}\end{array}$ \\
\hline Pride & $\begin{array}{c}0.39 * * * \\
{[0.36,0.41]}\end{array}$ & & & $\begin{array}{c}0.06 \\
{[-0.07,0.19]}\end{array}$ & $\begin{array}{c}0.10 \\
{[-0.05,0.24]}\end{array}$ \\
\hline Efficacy beliefs & $\begin{array}{c}0.46^{* * *} \\
{[0.43,0.48]}\end{array}$ & & & $\begin{array}{c}0.42^{* * *} \\
{[0.26,0.59]}\end{array}$ & $\begin{array}{c}0.52 * * * \\
{[0.33,0.70]} \\
\end{array}$ \\
\hline Social identity & $\begin{array}{c}0.58^{* * *} \\
{[0.56,0.60]}\end{array}$ & & & $\begin{array}{c}1.50 * * * \\
{[1.30,1.60]}\end{array}$ & $\begin{array}{c}1.40^{* * *} \\
{[1.20,1.50]}\end{array}$ \\
\hline Observations & & 3873 & 3718 & 4030 & 3563 \\
\hline $\begin{array}{l}\text { Nagelkerke's } \\
\text { Pseudo } R^{2}\end{array}$ & & 0.11 & 0.26 & 0.47 & 0.50 \\
\hline Log likelihood & & -2352.00 & -2051.00 & -1761.00 & -1524.00 \\
\hline AIC & & 4712.00 & 4110.00 & 3535.00 & 3072.00 \\
\hline
\end{tabular}

Note. Numbers in the upper part are standardized coefficients (odds ratios), except first column $(r)$, which shows Pearson correlations between each construct and participation in strikes. The $95 \%$ confidence intervals are in square brackets. ${ }^{* *} p<0.01 ;{ }^{* * *} p<0.001$. AIC $=$ Akaike Information Criterion.

The full model-where the explanatory power of each variable was assessed while holding all others constant--explained $50 \%$ of the variance in strike participation. In this model, social identity as a striker explained by far the most variance in strike participation $(\beta=1.40, S E=0.08, p<0.001)$. Level of formal education $(\beta=0.59, S E=0.07, p<0.001)$ and efficacy beliefs $(\beta=0.52, S E=0.09, p<0.001)$ were the second and third best constructs in explaining participation. Among risk perception variables, level of worry was strongly associated with participation $(\beta=0.37, S E=0.07, p<0.001)$. Moreover, younger respondents were more likely to participate than older ones $(\beta=-0.33, S E=0.07, p<0.001)$.

In the full model, somewhat surprisingly, the sign of the coefficients of severity and urgency changed compared to the zero-order correlations and the risk perception model such that higher scores were negatively associated with the likelihood of participating in strikes. The sign reversals are most likely statistical artefacts caused by multicollinearity, the shared variance between these predictors, social identity, and strike participation. 


\section{Discussion}

These results provide strong evidence that there are two clear types of psychological processes that are related to participation in climate strikes. The more powerful of these is the degree to which one identifies with others who strike. The strong explanatory power of social identity suggests that this construct is important to a similar degree in the context of the current climate change strikes to other contexts of collective action, despite the distinct characteristics of youth strikes compared to other collective action movements $[9,22]$. Second, participation in strikes is also related to risk perception, especially to worry (the affective component) and, to a lesser extent, to cognitive risk appraisals. The independent contributions of these theoretical frameworks highlight their relevance in understanding why young people strike and demand more action on climate change. Moreover, the explanatory power of all predictors together (Pseudo $R^{2}=0.50$ ) was comparable to similar research or even larger (e.g., [89,90]); thus, our findings also highlight the usefulness of combining the two frameworks.

Our findings point to different pathways for future research. First, it may be necessary to expand and adapt theories of collective action to the context of climate change. Most research on collective action assumes the existence of at least one group with whom people identify to some extent, and typically assumes a direct conflict with a second group (for critical discussions of these assumptions, see $[9,20,25])$. Although there are plausible in-groups and out-groups in the context of climate change (e.g., age groups, environmentalists vs. non-environmentalists, and nations that vary with respect to their contribution and vulnerability), research has yet to identify the groups that are theoretically and practically most relevant for those involved in activism. It is also not yet determined that a "perpetrator" out-group is a requirement for motivating collective action [20,25] (but see [10], which suggests the presence of a victim vs. perpetrator narrative within the youth climate movement). Our findings would suggest that, for climate change, this is not necessarily so, although we must interpret the lack of a significant finding in the case of anger and moral conviction with some caution. Instead, and somewhat speculatively, it could be argued that in this context, collective action is mainly motivated by the shared goal to protect the climate and the wellbeing of future beings.

With respect to risk perception, recent work shows that to understand perceptions and actions related to climate change, it is important to look more closely at how climate change could be personally relevant [91-93]. According to Wang and colleagues [93], it is unlikely that people perceive risks directly; rather, climate change is seen as a threat to things about which people care. Put differently, to understand risk-based collective action, it is essential to examine whether there are particular "objects of care" (e.g., one's family, vulnerable people, certain species or places, values such as justice and equality [93]) whose endangerment is particularly likely to lead to participation in strikes. Research by Fisher [52] suggests that for committed young activists, concerns about nature and social justice are important here.

This leads directly to a broader question, namely, whether and how processes concerning risk perception and social identity are connected. Further research is required to explore whether people link climate risks to their own group, and whether these links in turn increase collective action tendencies (e.g., where strikers feel climate change poses a particular threat to young people with whom they identify). Conversely, risk perceptions have the potential to lead to collective action without necessarily involving one's group. For instance, people could be concerned about other entities, such as the natural world or particularly vulnerable people $[45,94]$. Insights about the strength, causal direction, and boundary conditions of such relationships would advance our understanding of participation in collective action in the context of the complex social and ethical problem of climate change (for a more in-depth discussion of possible links between risk perceptions and social identity, see [25]).

Our findings provide insights for those who seek to promote and maintain collective action. The importance of social identity suggests that making it as easy as possible for people to relate to a movement and identify with its members could be a fulcrum to facilitate participation in climate strikes and wider activism [95]. This could be achieved in part by developing inclusive movements that pursue 
goals that are in the interests of many, something that cannot be taken for granted (see e.g., the discussion about inclusiveness in the extinction rebellion movement [96]). For social movements that prioritise high levels of participation, strategies to promote this may include participatory, consensus-oriented decision making [97] and refraining from actions that certain groups or individuals deem too extreme or make them feel excluded or unwelcome [98-100]. Creating inclusive movements may be easier among young people because their world-views—and corresponding positions on climate change [101]—are typically less entrenched than those of older people $[102,103]$. However, this notion will require further empirical evidence. Furthermore, the identified importance of risk perceptions and efficacy beliefs in the context of the youth climate strikes suggests that communicators should not shy away from highlighting risks alongside success stories and solutions; an honest recognition of problems caused by climate change is appropriate, if accompanied by efforts to promote collective efficacy [104-106]. Such a dual communication strategy would seem to be necessary in order to avoid the possibility that people are hopeful but passive [107] or complacent in light of past achievements [108]. In other words, an appropriate goal may be to make people aware that a greater level of action is sorely needed and that their participation is part of an effective response that can help to bring about that action.

Some possible limitations of the present research should be mentioned. First, there are questions around the generalizability of the findings. For one thing, the sample was not representative of young people in Switzerland. Women and respondents with more formal education were overrepresented. Representativeness is important when one wants to make claims about the prevalence of specific perceptions, beliefs, or attitudes in the population (e.g., "Most young people in Switzerland identify with people in the strike movements"). However, for studying relationships between psychological constructs, representativeness is less important as these typically hold across different segments of the population (e.g., higher levels of social identity should be associated with more activism irrespective of gender). Put differently, unrepresentative samples are typically unproblematic in terms of external validity (e.g., [109]).

For another, it can be questioned to what extent the findings can be generalized to other countries. For instance, it is possible that vulnerability to climate change influences risk perceptions, or that different national contexts (e.g., politicization of climate change) affect the extent to which members from different groups can be mobilized to strike for more action. These possible boundary conditions again caution against generalizing findings related to the prevalence of perceptions and behaviours. However, the observed relationships between the constructs examined should hold in other socio-political contexts. In sum, there are limitations to the extent to which our findings can be generalized to the population at large and other countries. These certainly offer room for future research but are unlikely to represent a significant threat to the main findings of this study.

Another limitation that offers opportunities for future research concerns the causal relationships between the studied constructs. We used a cross-sectional design and examined how well different constructs could "explain" participation in strikes. However, alternative causal pathways are also plausible, including a bidirectional relationship between social identity and participation in strikes. For instance, it could be that participating in strikes makes the climate crisis more salient and increases risk perceptions, or that people enjoy the atmosphere during the events and develop a shared social identity with other strikers. As such, participating in strikes could also give rise to a strong social identity as a striker, which in turn heightens the likelihood of further participation. To better understand such causal relationships, future research could use experimental designs to manipulate key variables or longitudinal designs to track changes across time.

\section{Conclusions}

The scale of climate change and the problems it presents for societies around the world are unprecedented. International youth climate strikes constitute a movement whose sudden growth has also been unprecedented. The presence of such peaceful grassroot movements has the potential to change societies [95] and contribute to the implementation of the major transformations required to 
limit global climate change [110]. Drawing on two hitherto separate lines of research-risk perceptions and social identity-based approaches to collective action-we have shown that both types of processes are associated with participation in youth strikes. As such, our research paves the way for a broader, more integrative understanding of collective action on climate change. The findings can benefit those interested in maintaining the current momentum of the youth strikes and help the strikes live up to their promise.

Supplementary Materials: The following are available online at http://www.mdpi.com/2071-1050/12/24/10605/s1, Table S1: Zero-order correlations (Pearson) of predictor variables, Table S2: Factor analysis of all seven constructs related to the ESIMCA model, Table S3: Factor analysis of constructs related to the ESIMCA model with five factors, Table S4: Factor analysis of constructs related to the ESIMCA model with five factors as used in the main analyses of the article, Table S5: Logistic regression models explaining participation in climate strikes (unstandardized odds ratios), Table S6: Logistic regression models explaining participation in climate strikes using the theoretically anticipated constructs as predictors (instead of the empirically derived factors), Table S7: Zero-order correlations (Pearson) between individual items and participation in strikes.

Author Contributions: A.B. conceptualized and designed the study, analysed and interpreted the data, wrote the first draft of the manuscript, and revised it. M.G. contributed to the design of the study and organized the recruitment of the respondents. M.G., K.S. and S.B.C. contributed to, refined, and revised the paper. All authors have read and agreed to the published version of the manuscript.

Funding: This research received no external funding.

Acknowledgments: We are very grateful to all respondents for participating in our research. We also thank Anja Mühlemann and Alexandre Mösching for their statistical advice. We further thank five anonymous reviewers for their critical evaluation of an earlier version of this manuscript and their constructive criticism.

Conflicts of Interest: The authors declare no conflict of interest. The authors declare that the research was conducted in the absence of any commercial or financial relationships that could be construed as a potential conflict of interest.

\section{References}

1. Hagedorn, G.; Kalmus, P.; Mann, M.; Vicca, S.; Van den Berge, J.; van Ypersele, J.-P.; Bourg, D.; Rotmans, J.; Kaaronen, R.; Rahmstorf, S.; et al. Concerns of young protesters are justified. Science 2019, 364, 139-140. [CrossRef]

2. Barasi, L. Guest Post: Polls Reveal Surge in Concern in UK about Climate Change. Carbon Brief 2019. Available online: https://www.carbonbrief.org/guest-post-rolls-reveal-surge-in-concern-in-uk-about-climate-change (accessed on 29 November 2019).

3. Thackeray, S.J.; Robinson, S.A.; Smith, P.; Bruno, R.; Kirschbaum, M.U.F.; Bernacchi, C.; Byrne, M.; Cheung, W.; Cotrufo, M.F.; Gienapp, P.; et al. Civil disobedience movements such as School Strike for the Climate are raising public awareness of the climate change emergency. Glob. Chang. Biol. 2020, 26, 1042-1044. [CrossRef] [PubMed]

4. Dennison, J. Europe's Greens Are on Fire... and It's Not Just Because of the Sweltering Heat. The Guardian, 28 July 2019. Available online: https://www.theguardian.com/commentisfree/2019/jul/28/europe-greens-onfire-and-not-just-because-of-sweltering-heat (accessed on 13 February 2020).

5. Sundblad, E.-L.; Biel, A.; Gärling, T. Intention to change activities that reduce carbon dioxide emissions related to worry about global climate change consequences. Eur. Rev. Appl. Psychol. Rev. Eur. Psychol. Appl. 2014, 64, 13-17. [CrossRef]

6. Xie, B.; Brewer, M.B.; Hayes, B.K.; McDonald, R.I.; Newell, B.R. Predicting climate change risk perception and willingness to act. J. Environ. Psychol. 2019, 65, 101331. [CrossRef]

7. Fisher, D.R. American Resistance: From the Women's March to the Blue Wave; Columbia University Press: New York, NY, USA, 2019; ISBN 978-0-231-54739-0.

8. Giugni, M.; Grasso, M.T. Street Citizens: Protest Politics and Social Movement Activism in the Age of Globalization; Cambridge University Press: Cambridge, UK, 2019; ISBN 978-1-108-47590-7.

9. van Zomeren, M.; Kutlaca, M.; Turner-Zwinkels, F. Integrating who "we" are with what "we" (will not) stand for: A further extension of the Social Identity Model of Collective Action. Eur. Rev. Soc. Psychol. 2018, 29, 122-160. [CrossRef] 
10. Han, H.; Ahn, S.W. Youth mobilization to stop global climate change: Narratives and impact. Sustainability 2020, 12, 4127. [CrossRef]

11. van Stekelenburg, J.; Klandermans, B. Individuals in movements: A social psychology of contention. In Handbook of Social Movements across Disciplines; Roggeband, C., Klandermans, B., Eds.; Springer: Cham, Switzerland, 2017; pp. 103-139. ISBN 978-3-319-57648-0.

12. van Zomeren, M.; Postmes, T.; Spears, R. On conviction's collective consequences: Integrating moral conviction with the social identity model of collective action. Br. J. Soc. Psychol. 2012, 51, 52-71. [CrossRef]

13. Wahlström, M.; Kocyba, P.; De Vydt, M.; De Moor, J. Protest for a Future: Composition, Mobilization and Motives of the Participants in Fridays for Future Climate Protests on 15 March 2019 in 13 European Cities. 2019. Available online: https://eprints.keele.ac.uk/6571/7/20190709_Protest\%20for\%20a\%20future_GCS\% 20Descriptive\%20Report.pdf (accessed on 13 February 2020).

14. De Moor, J.; Uba, K.; Wahlström, M.; Wennerhag, M.; De Vydt, M. Protest for a Future II: Composition, Mobilization and Motives of the Participants in Fridays for Future Climate Protests on 20-27 September 2019 in 19 Cities around the World. 2020. Available online: https:/gup.ub.gu.se/publication/290509 (accessed on 13 February 2020).

15. GFS Bern. Sensibilität in Klimafragen Führt zu Demonstrationen, Nicht Aber zu Besonders Klimafreundlichen Verhalten [Sensitivity to Climate Issues Leads to Demonstrations, but not to Particularly Climate-Friendly Behaviour]; GFS Bern: Bern, Switzerland, 2019; pp. 1-8.

16. SINUS. Die Jugend in Deutschland ist Wütend: Sie Fühlt Sich Beim Klimaschutz im Stich Gelassen [Young People in Germany are Angry: They Feel Abandoned When it Comes to Climate Protection]; SINUS: Heidelberg, Germany, 2019; pp. 1-12. Available online: https://www.sinus-institut.de/fileadmin/user_data/sinus-intranet/News_ Bilder/Klimaschutz/Pressematerialien_Jugend_Fridays_for_Future_und_Klimaschutz_SINUS-Institut.pdf (accessed on 10 December 2019).

17. Earl, J.; Maher, T.V.; Elliott, T. Youth, activism, and social movements. Sociol. Compass 2017, 11, e12465. [CrossRef]

18. Leiserowitz, A.; Maibach, E.; Rosenthal, S.; Kotcher, J.; Bergquist, P.; Gustafson, A.; Ballew, M.; Goldberg, M. Climate Activism: Beliefs, Attitudes, and Behaviors; Yale Program on Climate Change Communication: New Haven, CT, USA, 2019; pp. 1-38. Available online: https://climatecommunication.yale.edu/wp-content/ uploads/2020/02/global-warming-activism-november-2019.pdf (accessed on 16 November 2020).

19. Landmann, H.; Rohmann, A. Being moved by protest: Collective efficacy beliefs and injustice appraisals enhance collective action intentions for forest protection via positive and negative emotions. J. Environ. Psychol. 2020, 71, 101491. [CrossRef]

20. Bamberg, S.; Rees, J.H.; Schulte, M. Environmental protection through societal change: What psychology knows about collective climate action-And what it needs to find out. In Psychology and Climate Change; Clayton, S., Manning, C., Eds.; Academic Press: Cambridge, MA, USA, 2018; pp. 185-213. ISBN 9780-12-813130-5.

21. Klandermans, P.G. The Social Psychology of Protest; Blackwell: Oxford, UK, 1997.

22. van Zomeren, M.; Postmes, T.; Spears, R. Toward an integrative social identity model of collective action: A quantitative research synthesis of three socio-psychological perspectives. Psychol. Bull. 2008, 134, 504-535. [CrossRef]

23. Skitka, L.J. The psychology of moral conviction. Soc. Personal. Psychol. Compass 2010, 4, 267-281. [CrossRef]

24. van Zomeren, M. Four core social-psychological motivations to undertake collective action. Soc. Personal. Psychol. Compass 2013, 7, 378-388. [CrossRef]

25. Fritsche, I.; Barth, M.; Jugert, P.; Masson, T.; Reese, G. A social identity model of pro-environmental action (SIMPEA). Psychol. Rev. 2018, 125, 245-269. [CrossRef] [PubMed]

26. McFarland, S.; Webb, M.; Brown, D. All humanity is my ingroup: A measure and studies of identification with all humanity. J. Pers. Soc. Psychol. 2012, 103, 830-853. [CrossRef]

27. Renn, O. Three decades of risk research: Accomplishments and new challenges. J. Risk Res. 1998, 1, 49-71. [CrossRef]

28. Slovic, P.; Fischhoff, B.; Lichtenstein, S. Characterizing perceived risk. In Perilous Progress: Technology as a Hazard; Kates, R.W., Hohenemser, C., Kasperson, J.X., Eds.; Westview Press: Boulder, CO, USA, 1985; pp. 92-125. 
29. Leiserowitz, A. Climate change risk perception and policy preferences: The role of affect, imagery, and values. Clim. Chang. 2006, 77, 45-72. [CrossRef]

30. van der Linden, S.L. The social-psychological determinants of climate change risk perceptions: Towards a comprehensive model. J. Environ. Psychol. 2015, 41, 112-124. [CrossRef]

31. Bostrom, A.; Hayes, A.L.; Crosman, K.M. Efficacy, action, and support for reducing climate change risks. Risk Anal. 2019, 39, 805-828. [CrossRef]

32. Brügger, A.; Morton, T.A.; Dessai, S. Hand in hand: Public endorsement of climate change mitigation and adaptation. PLoS ONE 2015, 10, e0124843. [CrossRef]

33. Lee, T.M.; Markowitz, E.M.; Howe, P.D.; Ko, C.-Y.; Leiserowitz, A.A. Predictors of public climate change awareness and risk perception around the world. Nat. Clim. Chang. 2015, 5, 1014-1020. [CrossRef]

34. Poortinga, W.; Whitmarsh, L.; Steg, L.; Böhm, G.; Fisher, S. Climate change perceptions and their individual-level determinants: A cross-European analysis. Glob. Environ. Chang. 2019, 55, 25-35. [CrossRef]

35. Shi, J.; Visschers, V.H.M.; Siegrist, M.; Arvai, J. Knowledge as a driver of public perceptions about climate change reassessed. Nat. Clim. Chang. 2016, 6, 2997. [CrossRef]

36. Smith, N.; Leiserowitz, A. The role of emotion in global warming policy support and opposition. Risk Anal. 2014, 34, 937-948. [CrossRef] [PubMed]

37. Doran, R.; Böhm, G.; Pfister, H.-R.; Steentjes, K.; Pidgeon, N. Consequence evaluations and moral concerns about climate change: Insights from nationally representative surveys across four European countries. J. Risk Res. 2019, 22, 610-626. [CrossRef]

38. O'Connor, R.E.; Bord, R.J.; Fisher, A. Risk perceptions, general environmental beliefs, and willingness to address climate change. Risk Anal. 1999, 19, 461-471. [CrossRef]

39. Demski, C.; Capstick, S.B.; Pidgeon, N.; Sposato, R.G.; Spence, A. Experience of extreme weather affects climate change mitigation and adaptation responses. Clim. Chang. 2017, 140, 149-164. [CrossRef]

40. Ogunbode, C.A.; Demski, C.; Capstick, S.B.; Sposato, R.G. Attribution matters: Revisiting the link between extreme weather experience and climate change mitigation responses. Glob. Environ. Chang. 2019, 54, 31-39. [CrossRef]

41. Eitzinger, A.; Binder, C.R.; Meyer, M.A. Risk perception and decision-making: Do farmers consider risks from climate change? Clim. Chang. 2018, 151, 507-524. [CrossRef]

42. Renn, O. The social amplification/attenuation of risk framework: Application to climate change. Wiley Interdiscip. Rev. Clim. Chang. 2011, 2, 154-169. [CrossRef]

43. Steg, L.; Sievers, I. Cultural theory and individual perceptions of environmental risks. Environ. Behav. 2000, 32, 250-269. [CrossRef]

44. Bouman, T.; Verschoor, M.; Albers, C.J.; Böhm, G.; Fisher, S.D.; Poortinga, W.; Whitmarsh, L.; Steg, L. When worry about climate change leads to climate action: How values, worry and personal responsibility relate to various climate actions. Glob. Environ. Chang. 2020, 62, 102061. [CrossRef]

45. Howell, R.A. It's not (just) "the environment, stupid!" Values, motivations, and routes to engagement of people adopting lower-carbon lifestyles. Glob. Environ. Chang. 2013, 23, 281-290. [CrossRef]

46. Wolf, J.; Moser, S.C. Individual understandings, perceptions, and engagement with climate change: Insights from in-depth studies across the world. Wiley Interdiscip. Rev. Clim. Chang. 2011, 2, 547-569. [CrossRef]

47. Corner, A.; Roberts, O.; Chiari, S.; Völler, S.; Mayrhuber, E.S.; Mandl, S.; Monson, K. How do young people engage with climate change? The role of knowledge, values, message framing, and trusted communicators. Wiley Interdiscip. Rev. Clim. Chang. 2015, 6, 523-534. [CrossRef]

48. Lee, K.; Gjersoe, N.; O'Neill, S.; Barnett, J. Youth perceptions of climate change: A narrative synthesis. WIREs Clim. Chang. 2020, 11, e641. [CrossRef]

49. Nesdale, D.; Flesser, D. Social identity and the development of children's group attitudes. Child Dev. 2001, 72, 506-517. [CrossRef]

50. Eating Better. 2019 Youth Survey; YouGov: London, UK, 2019; pp. 1-9. Available online: https://www.eatingbetter.org/uploads/Documents/2019/Youth\%20Survey\%20slide\%20overview\%20final.pdf (accessed on 25 September 2020).

51. Ojala, M.; Lakew, Y. Young people and climate change communication. In Oxford Research Encyclopedia of Climate Science; Oxford University Press: Oxford, UK, 2017.

52. Fisher, S.R. Life trajectories of youth committing to climate activism. Environ. Educ. Res. 2016, 22, $229-247$. [CrossRef] 
53. Mead, E.; Roser-Renouf, C.; Rimal, R.N.; Flora, J.A.; Maibach, E.W.; Leiserowitz, A. Information seeking about global climate change among adolescents: The role of risk perceptions, efficacy beliefs, and parental influences. Atl. J. Commun. 2012, 20,31-52. [CrossRef]

54. Hornsey, M.J.; Harris, E.A.; Bain, P.G.; Fielding, K.S. Meta-analyses of the determinants and outcomes of belief in climate change. Nat. Clim. Chang. 2016, 6, 622-626. [CrossRef]

55. Crocetti, E.; Rubini, M. Communicating personal and social identity in adolescence. In The Oxford Encyclopedia of Intergroup Communication; Giles, H., Harwood, J., Eds.; Oxford University Press: New York, NY, USA, 2017; p. 1464.

56. Stevenson, K.T.; Peterson, M.N.; Bondell, H.D.; Moore, S.E.; Carrier, S.J. Overcoming skepticism with education: Interacting influences of worldview and climate change knowledge on perceived climate change risk among adolescents. Clim. Chang. 2014, 126, 293-304. [CrossRef]

57. Dinas, E. Opening "openness to change": Political events and the increased sensitivity of young adults. Polit. Res. Q. 2013, 66, 868-882. [CrossRef]

58. Sinatra, G.M.; Chinn, C.A. Thinking and reasoning in science: Promoting epistemic conceptual change. In APA Educational Psychology Handbook, Vol. 3: Application to Learning and Teaching; American Psychological Association: Washington, DC, USA, 2012; pp. 257-282. ISBN 978-1-4338-0999-6.

59. Dinas, E. The Impressionable Years: The Formative Role of Family, Vote and Political Events during Early Adulthood. Ph.D. Thesis, European University Institute, Florence, Italy, 2010.

60. Sears, D.O.; Brown, C. Childhood and adult political development. In The Oxford Handbook of Political Psychology; Huddy, L., Sears, D.O., Levy, J.S., Eds.; Oxford University Press: New York, NY, USA, 2013; pp. 59-95. ISBN 0-19-932881-1.

61. Eckstein, K.; Noack, P.; Gniewosz, B. Attitudes toward political engagement and willingness to participate in politics: Trajectories throughout adolescence. J. Adolesc. 2012, 35, 485-495. [CrossRef] [PubMed]

62. Fillieule, $\mathrm{O}$. The independent psychological effects of participation in demonstrations. Mobilization Int. $Q$. 2012, 17, 235-248. [CrossRef]

63. Federal Statistical Office. Permanent Resident Population by Age, Canton, District, and Municipality: 2019; Federal Statistical Office: Neuchâtel, Switzerland, 2020.

64. Federal Statistical Office. Students by Educational Level, Education Type, Age, and Canton: 2018-2019; Federal Statistical Office: Neuchâtel, Switzerland, 2020.

65. Steentjes, K.; Pidgeon, N.F.; Poortinga, W.; Corner, A.; Arnold, A.; Böhm, G.; Mays, C.; Poumadère, M.; Ruddat, M.; Scheer, D.; et al. European Perceptions of Climate Change: Topline Findings of a Survey Conducted in Four European Countries in 2016; Cardiff University: Cardiff, UK, 2017; pp. 1-69.

66. Brügger, A.; Morton, T.A.; Dessai, S. "Proximising" climate change reconsidered: A construal level theory perspective. J. Environ. Psychol. 2016, 46, 125-142. [CrossRef]

67. Dietz, T.; Dan, A.; Shwom, R. Support for climate change policy: Social psychological and social structural influences. Rural Sociol. 2007, 72, 185-214. [CrossRef]

68. Skitka, L.J.; Bauman, C.W.; Sargis, E.G. Moral conviction: Another contributor to attitude strength or something more? J. Pers. Soc. Psychol. 2005, 88, 895-917. [CrossRef]

69. Barth, M.; Jugert, P.; Wutzler, M.; Fritsche, I. Absolute moral standards and global identity as independent predictors of collective action against global injustice. Eur. J. Soc. Psychol. 2015, 45, 918-930. [CrossRef]

70. Bamberg, S.; Rees, J.; Seebauer, S. Collective climate action: Determinants of participation intention in community-based pro-environmental initiatives. J. Environ. Psychol. 2015, 43, 155-165. [CrossRef]

71. Rees, J.H.; Bamberg, S. Climate protection needs societal change: Determinants of intention to participate in collective climate action. Eur. J. Soc. Psychol. 2014, 44, 466-473. [CrossRef]

72. Tausch, N.; Becker, J.C. Emotional reactions to success and failure of collective action as predictors of future action intentions: A longitudinal investigation in the context of student protests in Germany. Br. J. Soc. Psychol. 2013, 52, 525-542. [CrossRef]

73. Saab, R.; Tausch, N.; Spears, R.; Cheung, W.-Y. Acting in solidarity: Testing an extended dual pathway model of collective action by bystander group members. Br. J. Soc. Psychol. 2015, 54, 539-560. [CrossRef] [PubMed]

74. van Zomeren, M.; Saguy, T.; Schellhaas, F.M.H. Believing in "making a difference" to collective efforts: Participative efficacy beliefs as a unique predictor of collective action. Group Process. Intergroup Relat. 2013, 16, 618-634. [CrossRef] 
75. Becker, J.C.; Tausch, N. When group memberships are negative: The concept, measurement, and behavioral implications of psychological disidentification. Self Identity 2014, 13, 294-321. [CrossRef]

76. Vatcheva, K.P.; Lee, M.; McCormick, J.B.; Rahbar, M.H. Multicollinearity in regression analyses conducted in epidemiologic studies. Epidemiology 2016, 6, 227. [CrossRef] [PubMed]

77. Menard, S. Standards for standardized logistic regression coefficients. Soc. Forces 2011, 89, 1409-1428. [CrossRef]

78. R Core Team. R: A Language and Environment for Statistical Computing [Computer Software]; R Foundation for Statistical Computing: Vienna, Austria, 2020.

79. RStudio Team. R Studio: Integrated Development for R [Computer Software]; RStudio, Inc.: Boston, MA, USA, 2018.

80. Wickham, H. Tidyverse [Computer Software]; RStudio, Inc.: Boston, MA, USA, 2019.

81. Revelle, W. Psych: Procedures for Psychological, Psychometric, and Personality Research [Computer Software]; Northwestern University: Evanston, IL, USA, 2020. Available online: https://CRAN.R-project.org/package= psych (accessed on 25 September 2020).

82. Fox, J.; Weisberg, S.; Price, B.; Adler, D.; Bates, D.; Baud-Bovy, G.; Bolker, B.; Ellison, S.; Firth, D.; Friendly, M.; et al. Car: Companion to Applied Regression [Computer Software]; Sage: Thousand Oaks, CA, USA, 2020. Available online: https://CRAN.R-project.org/package=car (accessed on 25 September 2020).

83. Signorell, A.; Aho, K.; Alfons, A.; Anderegg, N.; Aragon, T.; Arachchige, C.; Arppe, A.; Baddeley, A.; Barton, K.; Bolker, B.; et al. DescTools: Tools for Descriptive Statistics. 2020. Available online: https: //CRAN.R-project.org/package=DescTools (accessed on 25 September 2020).

84. Hlavac, M. Stargazer: Well-Formatted Regression and Summary Statistics Tables [Computer Software]; Central European Labour Studies Institute (CELSI): Bratislava, Slovakia, 2018. Available online: https://CRAN.Rproject.org/package=stargazer (accessed on 25 September 2020).

85. Zhu, H.; Travison, T.; Tsai, T.; Beasley, W.; Xie, Y.; Yu, G.; Laurent, S.; Shepherd, R.; Sidi, Y.; Salzer, B.; et al. kableExtra: Construct Complex Table with "Kable" and Pipe Syntax [Computer Software]. 2020. Available online: https://CRAN.R-project.org/package=kableExtra (accessed on 25 September 2020).

86. Stanley, D. apaTables: Create American Psychological Association (APA) Style Tables [Computer Software]. 2018. Available online: https://CRAN.R-project.org/package=apaTables (accessed on 25 September 2020).

87. DeWitt, P.; Bennett, T. Qwraps2: Quick Wraps 2. 2020. Available online: https://CRAN.R-project.org/ package $=$ qwraps2 (accessed on 25 September 2020).

88. van der Linden, S. Determinants and measurement of climate change risk perception, worry, and concern. In The Oxford Encyclopedia of Climate Change Communication; Oxford University Press: Oxford, UK, 2017. [CrossRef]

89. Fernandes-Jesus, M.; Lima, M.L.; Sabucedo, J.-M. "Save the climate! stop the oil”: Actual protest behavior and core framing tasks in the Portuguese climate movement. J. Soc. Polit. Psychol. 2020, 8, 426-452. [CrossRef]

90. Roser-Renouf, C.; Maibach, E.W.; Leiserowitz, A.; Zhao, X. The genesis of climate change activism: From key beliefs to political action. Clim. Chang. 2014, 125, 163-178. [CrossRef]

91. Brügger, A. Understanding the psychological distance of climate change: The limitations of construal level theory and suggestions for alternative theoretical perspectives. Glob. Environ. Chang. 2020, 60, 102023. [CrossRef]

92. Brügger, A.; Dessai, S.; Devine-Wright, P.; Morton, T.A.; Pidgeon, N.F. Psychological responses to the proximity of climate change. Nat. Clim. Chang. 2015, 5, 1031-1037. [CrossRef]

93. Wang, S.; Leviston, Z.; Hurlstone, M.; Lawrence, C.; Walker, I. Emotions predict policy support: Why it matters how people feel about climate change. Glob. Environ. Chang. 2018, 50, 25-40. [CrossRef]

94. Howell, R.A.; Allen, S. People and planet: Values, motivations and formative influences of individuals acting to mitigate climate change. Environ. Values 2017, 26, 131-155. [CrossRef]

95. Chenoweth, E.; Stephan, M.J. Why Civil Resistance Works: The Strategic Logic of Nonviolent Conflict; Columbia University Press: New York, NY, USA, 2011; ISBN 978-0-231-52748-4.

96. Gayle, D. Does Extinction Rebellion Have a Race Problem? The Guardian. 4 October 2019. Available online: https://www.theguardian.com/environment/2019/oct/04/extinction-rebellion-race-climate-crisisinequality (accessed on 2 December 2020).

97. della Porta, D. Democracy in Social Movements; Palgrave Macmillan: London, UK, 2009; ISBN 978-0-230-24086-5. 
98. Feinberg, M.; Willer, R.; Kovacheff, C. The activist's dilemma: Extreme protest actions reduce popular support for social movements. J. Pers. Soc. Psychol. 2020, 119, 1086-1111. [CrossRef] [PubMed]

99. Simpson, B.; Willer, R.; Feinberg, M. Does violent protest backfire? Testing a theory of public reactions to activist violence. Socius 2018, 4, 1-14. [CrossRef]

100. Stuart, A.; Thomas, E.F.; Donaghue, N. "I don't really want to be associated with the self-righteous left extreme": Disincentives to participation in collective action. J. Soc. Polit. Psychol. 2018, 6, 242-270. [CrossRef]

101. Kahan, D.M.; Peters, E.; Wittlin, M.; Slovic, P.; Ouellette, L.L.; Braman, D.; Mandel, G. The polarizing impact of science literacy and numeracy on perceived climate change risks. Nat. Clim. Chang. 2012, 2, 732-735. [CrossRef]

102. Harker-Schuch, I. Why is early adolescence so pivotal in the climate change communication and education arena? In Climate Change and the Role of Education; Leal Filho, W., Hemstock, S.L., Eds.; Climate Change Management; Springer International Publishing: Cham, Switzerland, 2019; pp. 279-290. ISBN 978-3-030-32898-6.

103. Vollebergh, W.A.M.; Iedema, J.; Raaijmakers, Q.A.W. Intergenerational transmission and the formation of cultural orientations in adolescence and young adulthood. J. Marriage Fam. 2001, 63, 1185-1198. [CrossRef]

104. Chen, M.-F. Impact of fear appeals on pro-environmental behavior and crucial determinants. Int. J. Advert. 2016, 35, 74-92. [CrossRef]

105. Marlon, J.R.; Bloodhart, B.; Ballew, M.T.; Rolfe-Redding, J.; Roser-Renouf, C.; Leiserowitz, A.; Maibach, E. How hope and doubt affect climate change mobilization. Front. Commun. 2019, 4, 20. [CrossRef]

106. Peters, G.-J.Y.; Ruiter, R.A.C.; Kok, G. Threatening communication: A critical re-analysis and a revised meta-analytic test of fear appeal theory. Health Psychol. Rev. 2013, 7, S8-S31. [CrossRef] [PubMed]

107. van Zomeren, M.; Pauls, I.L.; Cohen-Chen, S. Is hope good for motivating collective action in the context of climate change? Differentiating hope's emotion- and problem-focused coping functions. Glob. Environ. Chang. 2019, 58, 101915. [CrossRef]

108. Hornsey, M.J.; Fielding, K.S. A cautionary note about messages of hope: Focusing on progress in reducing carbon emissions weakens mitigation motivation. Glob. Environ. Chang. 2016, 39, 26-34. [CrossRef]

109. Druckman, J.N.; Kam, C.D. Students as experimental participants: A defense of the "narrow data base". In Cambridge Handbook of Experimental Political Science; Druckman, J.N., Green, D.P., Kuklinski, J.H., Lupia, A., Eds.; Cambridge University Press: Cambridge, UK, 2011; pp. 41-57.

110. UNFCCC. Paris Agreement United Nations Framework Convention on Climate Change; UNFCCC: Paris, France, 2015. Available online: https://unfccc.int/files/meetings/paris_nov_2015/application/pdf/paris_agreement_ english_.pdf (accessed on 10 December 2019).

Publisher's Note: MDPI stays neutral with regard to jurisdictional claims in published maps and institutional affiliations.

(C) 2020 by the authors. Licensee MDPI, Basel, Switzerland. This article is an open access article distributed under the terms and conditions of the Creative Commons Attribution (CC BY) license (http://creativecommons.org/licenses/by/4.0/). 